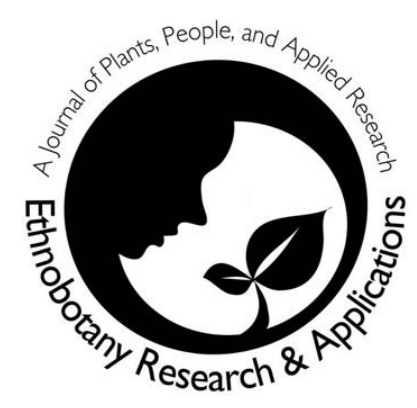

\title{
Ethnomedicinal knowledge on the precise use of herbal medicine - An interview- based study on traditional healers from Jaunsar- Bawar region of Uttarakhand
}

\author{
Deepak Kumar Semwal, Ankit Kumar, Ashutosh \\ Chauhan, Ruchi Badoni Semwal, Ravindra Semwal, and \\ Sunil Kumar Joshi
}

\section{Research}

\begin{abstract}
Background: Jaunsar-Bawar region of Uttarakhand is well-known for its rich biodiversity. In continuation of our previous field survey on traditional medicinal plants used in diabetes mellitus, this study was designed to gather traditional knowledge about when and how the herbal remedies are used for different ailments by the tribal people.
\end{abstract}

Methods: Information about the use of medicinal plants was collected from different folk healers of the region. The plant specimens were collected from their natural habitat and authenticated in the laboratory of Materia Medica and Taxonomy.

Results: Out of the 200 plants, 41 species belonging to 27 families have been explored in this study based on their availability and potency. Most of the selected plants were found to be used topically while a few were suggested for oral use. These plants have been found effective in curing cuts, wounds, boils, bone fracture, muscular pain, inflammation, fever, mouth ulcer, stomach ache, headache and many other conditions.

Conclusion: The study concludes that these plants have the potential to treat various health conditions. Exploration of these plants scientifically will be a great addition to the field of herbal medicine.

Keywords: Ethnomedicine, anti-fungal activity, traditional knowledge, Ayurveda, herbal medicine

\section{Correspondence}

Deepak Kumar Semwal ${ }^{1 *}$, Ankit Kumar ${ }^{2}$, Ashutosh Chauhan ${ }^{3}$, Ruchi Badoni Semwal ${ }^{4}$, Ravindra Semwal ${ }^{2}$, and Sunil Kumar Joshi ${ }^{5}$

${ }^{1}$ Department of Phytochemistry, Faculty of Biomedical Sciences, Uttarakhand Ayurved University, Harrawala, Dehradun-248001, India.

${ }^{2}$ Research and Development Centre, Faculty of Biomedical Sciences, Uttarakhand Ayurved University, Harrawala, Dehradun-248001, India.

${ }^{3}$ Department of Biotechnology, Faculty of Biomedical Sciences, Uttarakhand Ayurved University, Harrawala, Dehradun-248001, India.

${ }^{4}$ Department of Chemistry, Pt. Lalit Mohan Sharma Government Postgraduate College, Rishikesh- 249201, Uttarakhand, India.

5Uttarakhand Ayurved University, Harrawala, Dehradun-248001, India.

"Corresponding Author: Deepak Kumar Semwal; Email: dr_dks.1983@yahoo.co.in

Ethnobotany Research \& Applications 21:32 (2021) 


\section{Background}

According to the World Health Organization, the Traditional Health Care System is considered to be the best for curing diseases, and is used by $70 \%$ of the world population (WHO 2019). In many cases like chronic conditions, traditional medicine has proved its potential over modern biomedicine. Various research reports proved that synthetic drugs have many side effects both acute and chronic while herbal treatment is considered safe. Besides, herbal medication is comparatively cheaper than synthetic drugs, and hence, considered more economical for all. As a result, people from all over the world are again shifting back to herbal medicine due to economic and safe. Indian Traditional Systems of Medicine, such folk medicine and as the codified Ayurveda use monoherbal and polyherbal formulations that can be prepared by the patients themselves without depending on a practitioner (Semwal et al. 2019).

The folk medicinal system of Uttarakhand uses a large variety of medicinal plants. To date, about 1500 folklore plants including Ayurvedic herbs have been reported in Uttarakhand with an area of 53,483 square kilometres. With varied agro-climatic region, Uttarakhand is rich in Medicinal and Aromatic Plants (MAPs) and is counted among the mega biodiversity regions of the world. Uttarakhand has a long history of folk medicines which are generally used for most of the ordinary ailments and mainly used by the tribal population of the region such as Jaunsari, Tharu, Raji, Buksa and Bhotiya tribes (Shah 1982). Likewise, the western hilly part of Nepal, an adjacent area to Uttarakhand state, is also known for its rich biodiversity and traditional knowledge. The climate of this area favours to growth of a variety of medicinal plants of industrial value that include Acacia catechu, Bacopa monnieri, Bombax ceiba, Drymaria diandra, Rauvolfia serpentina and Tribulus terrestris (Shrestha \& Dhillion 2003; Singh et al. 2012; Adhikari et al. 2019).

The present study area Jaunsar-Bawar (Fig. 1), is situated in the Dehradun district of Uttarakhand and comprised of hill areas. This area lies in the border with Himachal Pradesh, with river Yamuna in the east and river Tons in the west, while Uttarkashi district is situated at its northern part. Kalsi, Sahiya, Chakrata, Debvan, Hanol, and Lakhamandal are among the most popular places in this region. In the past, many surveys have been conducted in different areas of the Uttarakhand state of India mainly in tribal areas (Joshi \& Pant 2012; Sharma et al. 2013; Khajuria \& Bisht 2017; Singh et al. 2019). However, the present study area is least explored for its folk medicine. The present study reports precise information about the doses, duration of the treatment and mode of administration of medicinal plants used in the folk medicine by the inhabitants of Jaunsar and Bawar areas of Uttarakhand for the first time.

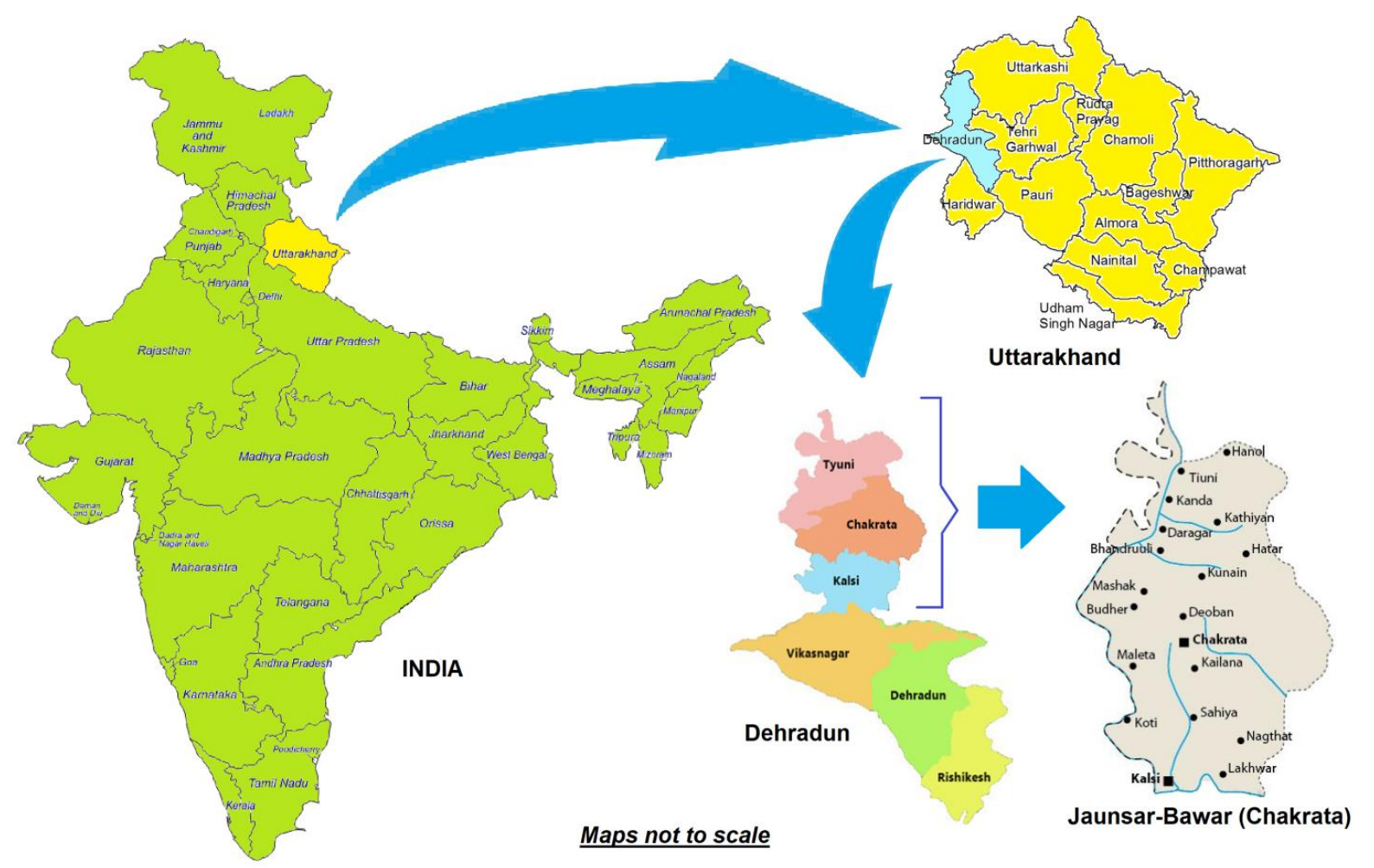

Fig. 1. Geographical location of Jaunsar-Bawar 


\section{Materials and methods}

Field survey was conducted during the year between 2017 and 2020. A total of 8 visits of 3-5 days were conducted in the study area covering almost all the areas in different seasons included in our previous survey (Kumar et al. 2019). The information about the local uses of these medicinal plants was collected from the local folk practitioners, cattle feeders and elder villagers. In this study, a total of 22 folk healers ( 17 male and 5 female) of $45-85$ years of age were interviewed. The participants were identified by enquiring local people. A few healers having expertise in a specific disease, such as kidney stone, diabetes, hypertension and snakebite, were also interviewed. Practitioners who did not share the proper information about the medicinal use of the herbs were excluded from the study. Before the individual interview, verbal consent was taken from each participant and already informed them to publicise their experience-based knowledge globally for humankind. During the interview, photographs with all the participants were taken; selected pictures are given in Fig. 2.

Information was recorded in the standard questionnaire which included the local name of the medicinal plant, parts used, method of preparation, mode of administration, probable dosage and duration of treatment. As per the information, the plant samples were also collected from the study area to deposit their specimens to Uttarakhand Ayurved University (UAU) herbarium. The voucher specimen number of each plant is given in Table 1. The plant samples were identified with the help of local names given in the local floras published in previous years (Gaur 1999; Kanjilal 2011). Scientific authentication of the plants was done at the Research and Development Centre of UAU. The information about the medicinal plants during the field visit was cross-checked from the ancient Ayurvedic literature and scientific papers available online. A flow chart showing step-wise study design is given in Fig. 3 .
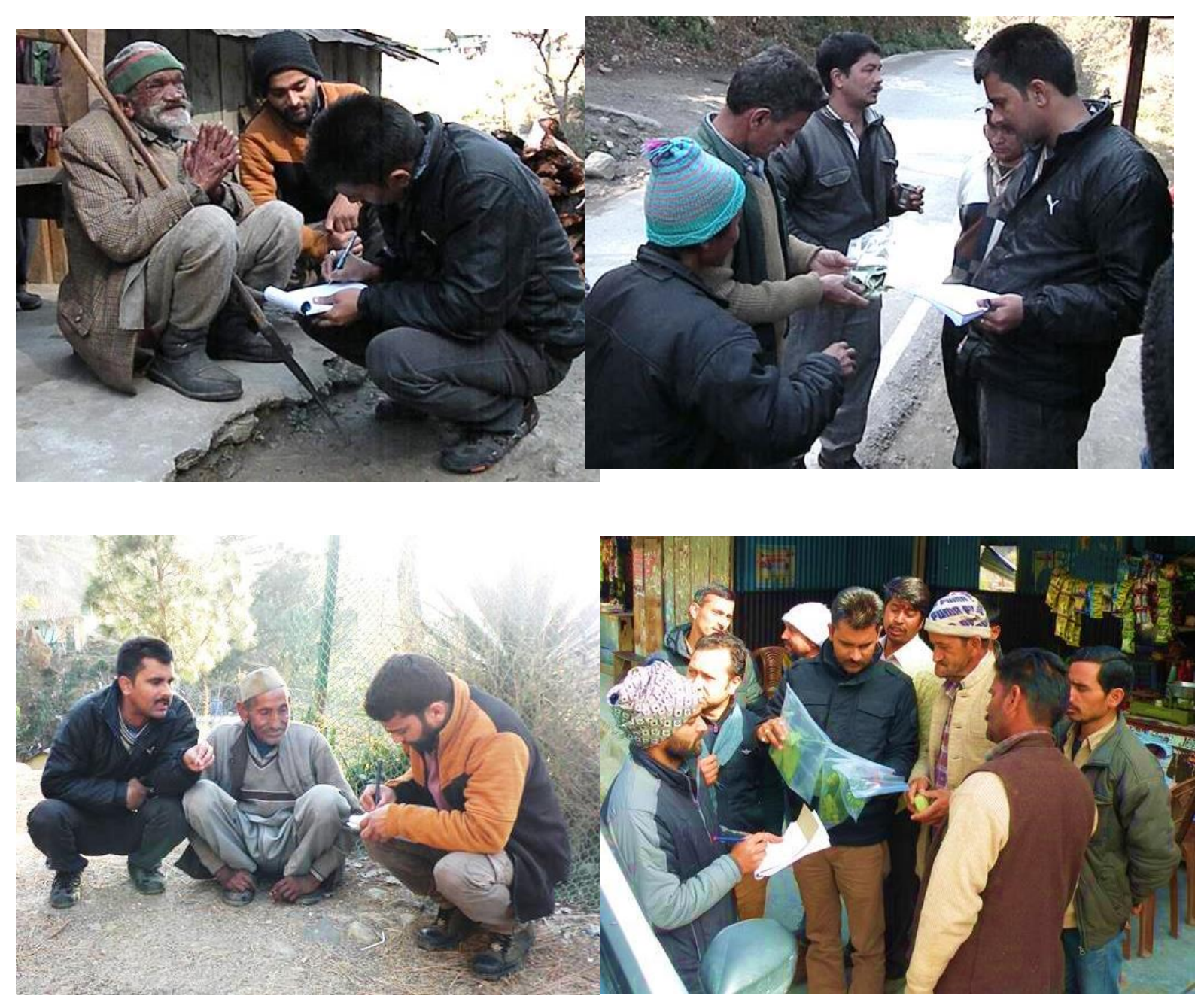

Fig. 2. Photographs of interview with traditional healers 


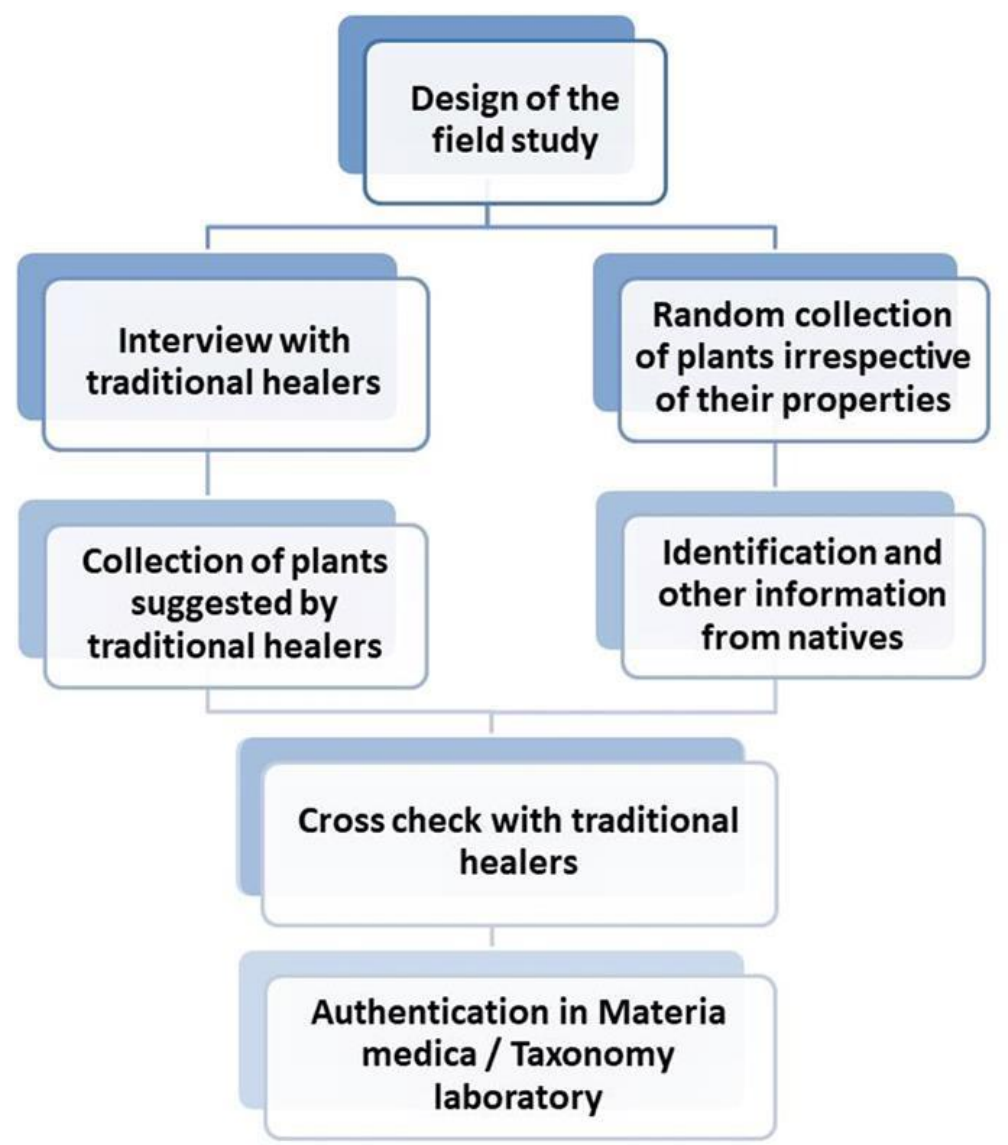

Fig. 3. Step-wise study design of the fieldwork

\section{Results}

The research revealed Jaunsar-Bawar region of Uttarakhand has a difficult geographical terrain and also lacks advanced medical facilities. Most of the people in this region are dependent on herbal medicines for their primary healthcare as they prefer higher medical centres only in serious conditions. The farmers, hunters, shepherds and grass cutters of this area are well-acquainted with the herbal remedies for primary healthcare and folk healers/ vaidyas are also consulted in cases of serious problems. The cattle feeders shared valuable information during the interview as their life is closely connected with the forested areas and plant wealth. They are mostly dependent on natural medicine when living in the forest region with their cattle. More than 200 plant species were recorded during the field survey, and based on information collected from the natives, 41 species were found to have therapeutical importance in the traditional medical system of this region. Based on the interview with local traditional healers and other elders, the information about herbal remedies is shown in Table 1. As the activity of a herb depends on its active constituents, selected bioactives found in these herbs are also given in Table 2.

\section{Data analysis}

Analysis of collected data on ethnomedicinal plants revealed that Leguminosae was the largest represented family with a total of five members whereas three members each were recorded for Apiaceae, Compositae, Lamiaceae and Ranunculaceae families (Fig. 4). Among them, a majority of plants (7) were found effective in fever, followed by bone-fracture/ joint pain (6) and cuts/ wounds (5) in which two plant species were found effective in more than one health conditions. The distribution of plants based on their uses against different medical conditions is shown in Fig. 5. Similarly, most of the plants used by traditional healers belong to herbs (23) that cover $56 \%$ of total plants, whereas the shrubs (9) cover only $22 \%$ (Fig. $6)$. Leaves (18) were the most used part in ethnomedicine followed by roots or underground parts (15). Moreover, topical route was recorded as the most accepted route for drug administration followed by the oral route. The pictures of selected medicinal plants are given in Fig. 7. 


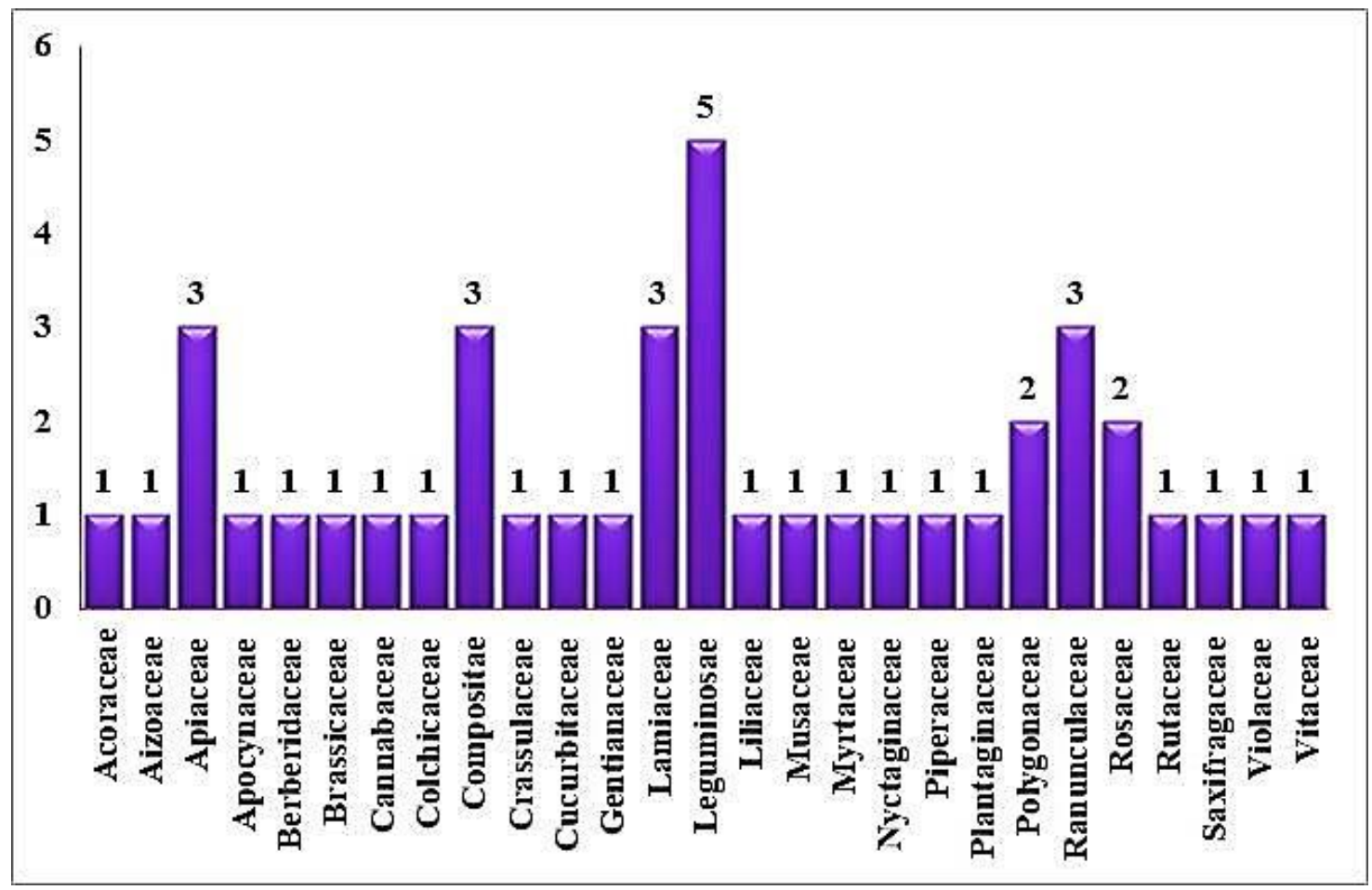

Fig. 4. Family-wise distribution of medicinal plants

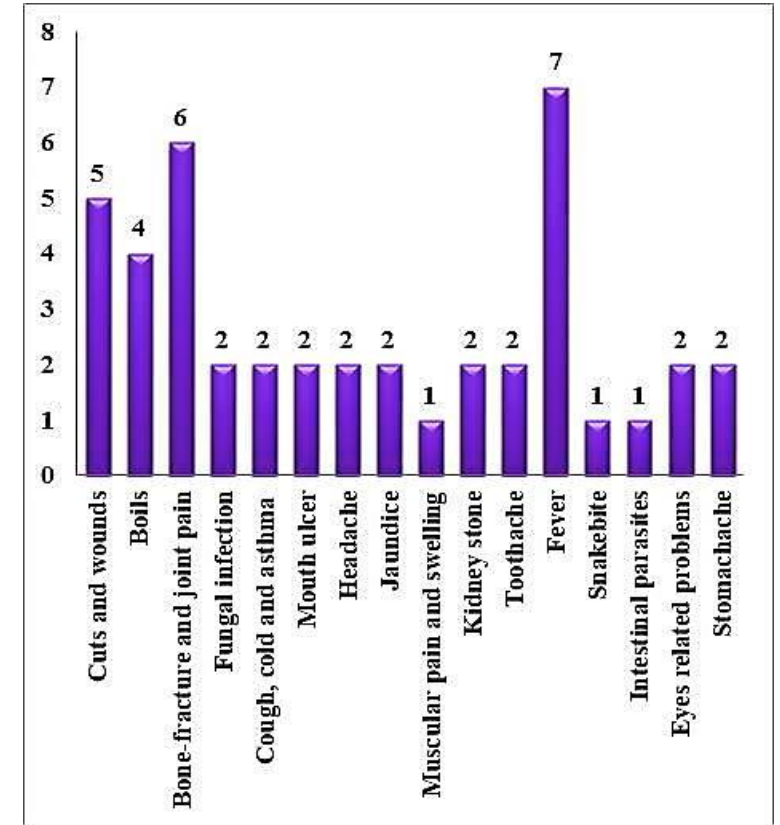

Fig. 5. Application-wise distribution of medicinal plants

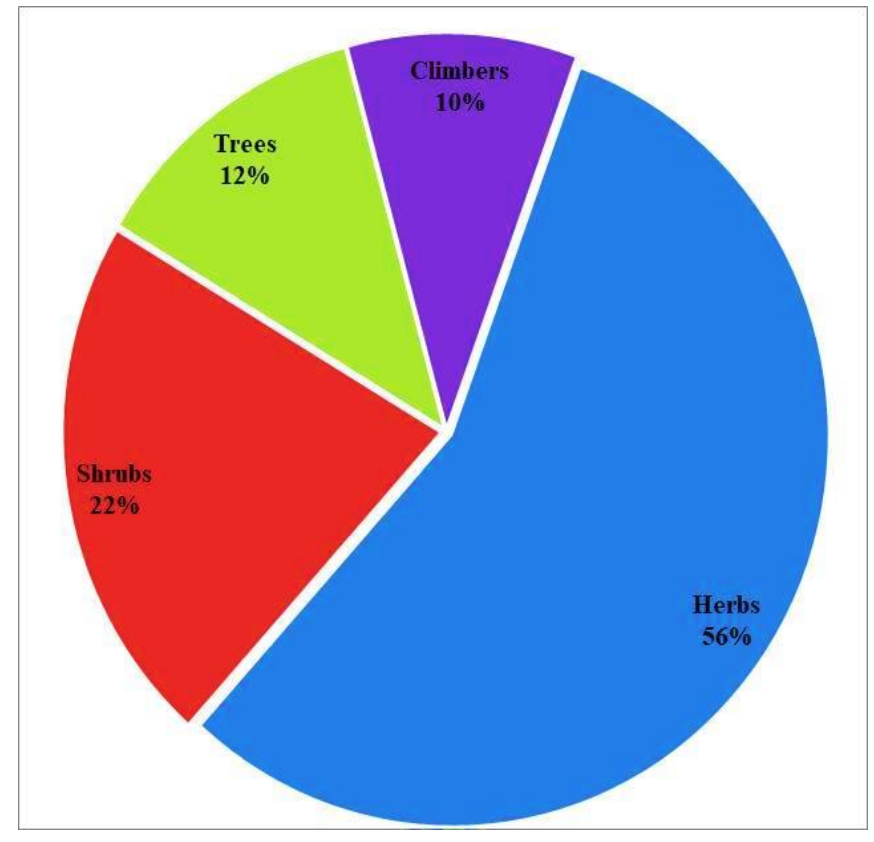

Fig. 6. Category-wise percentage of medicinal plants 
Table 1. Medicinal plants and their traditional uses with key identification features

\begin{tabular}{|c|c|c|c|c|c|}
\hline $\begin{array}{l}\text { Family and } \\
\text { name of plant }\end{array}$ & $\begin{array}{l}\text { Common } \\
\text { names }\end{array}$ & $\begin{array}{l}\text { Voucher } \\
\text { number }\end{array}$ & $\begin{array}{l}\text { Life form } \\
\text { / Part } \\
\text { used }\end{array}$ & Traditional use & $\begin{array}{l}\text { Key identification } \\
\text { features }\end{array}$ \\
\hline \multicolumn{6}{|l|}{ Acoraceae } \\
\hline $\begin{array}{l}\text { Acorus calamus } \\
\mathrm{L} \text {. }\end{array}$ & $\begin{array}{l}\text { Vaca / } \\
\text { Sweet flag / } \\
\text { Bach }\end{array}$ & UAU212 & $\begin{array}{l}\text { Herb / } \\
\text { rhizome }\end{array}$ & $\begin{array}{l}\text { Decoction or infusion of } \\
\text { rhizome }(1 \mathrm{~g}) \text { is given to } \\
\text { children to kill infectious } \\
\text { worms of GIT. The } \\
\text { garland of its rhizome } \\
\text { also kills worms. }\end{array}$ & $\begin{array}{l}\text { A semi-aquatic } \\
\text { perennial herb; } \\
\text { rhizome creeping, } \\
\text { much-branched, } \\
\text { cylindrical; leaves } \\
\text { bright green, thickened } \\
\text { in middle; flowers light } \\
\text { brown densely packed } \\
\text { in sessile; fruits oblong } \\
\text { turbinate with a } \\
\text { pyramidal top; seeds } \\
\text { free and pendant from } \\
\text { the apex. }\end{array}$ \\
\hline
\end{tabular}

\begin{tabular}{llll}
\hline Aizoaceae & & & \\
\hline Trianthema & Bishkopra / & UAU213 & Herb / \\
portulacastrum L. & $\begin{array}{l}\text { Black } \\
\text { pigweed }\end{array}$ & & $\begin{array}{l}\text { aerial } \\
\text { parts }\end{array}$
\end{tabular}

$\begin{array}{ll}\begin{array}{ll}\text { Powder of aerial parts (1- } \\ 3 \mathrm{~g} \text { ) is given with boil }\end{array} & \begin{array}{l}\text { An annual herb with a } \\ \text { prostrate mat or clump }\end{array} \\ \begin{array}{l}\text { water in fever. Decoction } \\ \text { of powder can also be }\end{array} & \begin{array}{l}\text { made by its stems; } \\ \text { leaves have round or } \\ \text { used in place of dry }\end{array} \\ \begin{array}{ll}\text { oval blades borne on } \\ \text { power. The treatment is }\end{array} & \begin{array}{l}\text { petioles; solitary } \\ \text { flowers occur in leaf }\end{array} \\ \text { three days for better } & \text { axils with purple and } \\ \text { results. The decoction is } & \text { petal-like sepals; fruit } \\ \text { also useful in } & \text { curved and cylindrical } \\ \text { rheumatism and alcohol } & \text { capsule. }\end{array}$

Apiaceae poisoning.

\begin{tabular}{|c|c|c|c|c|}
\hline $\begin{array}{l}\text { Cuminum } \\
\text { cyminum L. }\end{array}$ & Cumin / Jira & UAU214 & $\begin{array}{l}\text { Herb / } \\
\text { seeds }\end{array}$ & $\begin{array}{l}\text { Tea prepared from the } \\
\text { seeds }(2-3 \mathrm{~g}) \text { is used in } \\
\text { stomachache. Decoction } \\
\text { prepared with one } \\
\text { teaspoon }(3 \mathrm{~g}) \text { of seeds } \\
\text { in } 100 \mathrm{~mL} \text { of water is } \\
\text { taken in the complaint of } \\
\text { abdominal pain. }\end{array}$ \\
\hline
\end{tabular}

\begin{tabular}{llll}
\hline Seseli diffusum & Van ajwain / & UAU215 & $\begin{array}{l}\text { Herb / } \\
\text { leaf }\end{array}$
\end{tabular}

Santapau \&

Wagh (Syn.

Seseli indicum

Wight \& Arn.)
Fresh leaves $(2-3 \mathrm{~g})$ are decoction of mature consumed twice a day to relieve fever. Leaves are chewed in stomachache and other gastric problems. chewed in fever. The hot seeds $(1-3 \mathrm{~g})$ is

An annual herb that grows to $50 \mathrm{~cm}$ high; stem cylindrical, glabrous, branched; leaves pinnate or bipinnate with threadlike leaflets; flowers small, white or pink, borne in umbels; fruit lateral fusiform or ovoid achene with two mericarps having single seed.

An annual herb with Ajwain

(Trachyspermum ammi)-like fragrance; leaves bipinnate, segments ovate; rays pubescent, involucel comprised of 5-8 linear bractlets; calyx teeth minute; fruit small, hispid.

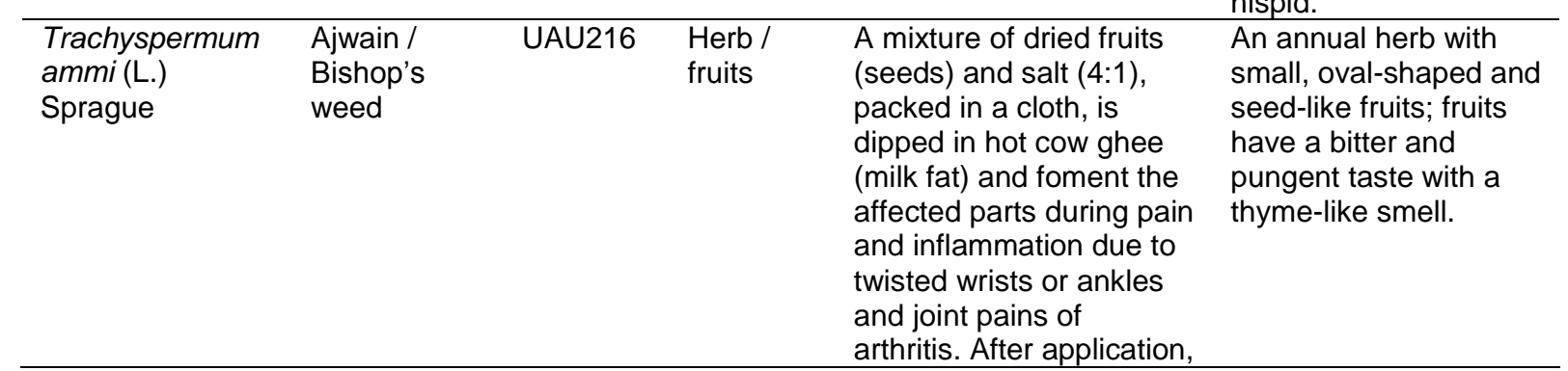




\begin{tabular}{|c|c|c|c|c|c|}
\hline & & & & $\begin{array}{l}\text { the body part is plucked } \\
\text { by a strip of cotton cloth } \\
\text { for } 2-3 \text { hours. The } \\
\text { treatment should be } \\
\text { repeated twice a day for } \\
\text { several days until getting } \\
\text { relief. A hot decoction of } \\
\text { fruits }(3-5 \mathrm{~g}) \text { is given in } \\
\text { high fever. After } \\
\text { consumption, the patient } \\
\text { is advised to wrapping in } \\
\text { a blanket, once the } \\
\text { sweating comes out, the } \\
\text { patient feels relaxed. }\end{array}$ & \\
\hline \multicolumn{6}{|l|}{ Apocynaceae } \\
\hline $\begin{array}{l}\text { Holarrhena } \\
\text { pubescens Wall. } \\
\text { ex G.Don }\end{array}$ & $\begin{array}{l}\text { Kutaja / } \\
\text { Coral swirl / } \\
\text { Tellicherry } \\
\text { bark / Koriya } \\
\text { / Kurchi / } \\
\text { Kueya / } \\
\text { Kuda }\end{array}$ & UAU217 & $\begin{array}{l}\text { Shrub / } \\
\text { stem or } \\
\text { leaf }\end{array}$ & $\begin{array}{l}\text { Milky latex (3-5 drops) of } \\
\text { stem or leaf petiole of a } \\
\text { mature plant is applied } \\
\text { on the boils in a circular } \\
\text { form to treat boils. The } \\
\text { latex is applied twice a } \\
\text { day up to } 3-5 \text { days in } \\
\text { such a way so that it can } \\
\text { cover the whole affected } \\
\text { part to stop the growth of } \\
\text { boils, relieve pain and } \\
\text { heal the boil } \\
\text { permanently. }\end{array}$ & $\begin{array}{l}\text { A large shrub up to } 3 \\
\text { m tall; bark thick pale } \\
\text { brown, rough with a } \\
\text { milky latex, which } \\
\text { peels off easily; leaves } \\
\text { simple, opposite; } \\
\text { flowers white, fragrant, } \\
\text { terminal corymbose } \\
\text { cymes; seeds yellow }\end{array}$ \\
\hline \multicolumn{6}{|l|}{ Berberidaceae } \\
\hline $\begin{array}{l}\text { Berberis aristata } \\
\text { DC. }\end{array}$ & $\begin{array}{l}\text { Daruharidra } \\
\text { / Indian } \\
\text { Barberry / } \\
\text { Kingor }\end{array}$ & UAU218 & $\begin{array}{l}\text { Shrub / } \\
\text { root }\end{array}$ & $\begin{array}{l}\text { Two to three drops of } \\
\text { roots decoction are } \\
\text { externally used for eyes } \\
\text { infection and burning/ red } \\
\text { eyes during summers. }\end{array}$ & $\begin{array}{l}\text { An erect woody shrub; } \\
\text { outer bark yellow to } \\
\text { brown, inner bark dark } \\
\text { yellow; leaves } \\
\text { arranged in tufts of 5- } \\
8 \text {; flowers yellow, } \\
\text { developed in a } \\
\text { racemose } \\
\text { inflorescence; fruits } \\
\text { ovoid, succulent, } \\
\text { acidic, bright red or } \\
\text { bluish-purple. }\end{array}$ \\
\hline \multicolumn{6}{|l|}{ Brassicaceae } \\
\hline $\begin{array}{l}\text { Brassica nigra } \\
\text { (L.) K.Koch }\end{array}$ & $\begin{array}{l}\text { Mustered/ } \\
\text { Sarson/ } \\
\text { Laiya }\end{array}$ & UAU219 & $\begin{array}{l}\text { Herb / } \\
\text { seed }\end{array}$ & $\begin{array}{l}\text { Massage of a mixture of } \\
\text { mustard oil (seed oil) and } \\
\text { water in 1:1 ratio on the } \\
\text { forehead is used to get } \\
\text { rid of headache. }\end{array}$ & $\begin{array}{l}\text { An annual herb with } \\
\text { large stalked leaves; } \\
\text { flowers yellow, borne } \\
\text { at the top of the stem, } \\
\text { petals longer than } \\
\text { sepals; pod contains 4- } \\
5 \text { tiny black seeds. }\end{array}$ \\
\hline \multicolumn{6}{|l|}{ Cannabaceae } \\
\hline Celtis australis L. & $\begin{array}{l}\text { Khadik / } \\
\text { European } \\
\text { nettle tree / } \\
\text { Mediterrane } \\
\text { an hackberry }\end{array}$ & UAU220 & $\begin{array}{l}\text { Tree / } \\
\text { stem } \\
\text { bark }\end{array}$ & $\begin{array}{l}\text { Paste of fresh bark is } \\
\text { used in bone fracture, } \\
\text { contusions, sprains and } \\
\text { joint pains. A plaster of } \\
\text { the bark paste is applied } \\
\text { to the damaged portion } \\
\text { with the help of a cloth } \\
\text { and left for several days } \\
\text { to repair the broken } \\
\text { bone. }\end{array}$ & $\begin{array}{l}\text { A medium to a large } \\
\text { tree of up to } 25 \text { m high; } \\
\text { bark pale, ashy or } \\
\text { grey, smooth; leaves } \\
\text { ovate, rounded base, } \\
\text { dull green; flowers } \\
\text { greenish; fruits small, } \\
\text { dark-purple berry-like } \\
\text { drupes. }\end{array}$ \\
\hline \multicolumn{6}{|l|}{ Colchicaceae } \\
\hline $\begin{array}{l}\text { Gloriosa superba } \\
\text { L. }\end{array}$ & $\begin{array}{l}\text { Kalihari / } \\
\text { Tiger claw / } \\
\text { Langly }\end{array}$ & UAU221 & $\begin{array}{l}\text { Climber / } \\
\text { tuber }\end{array}$ & $\begin{array}{l}\text { Paste of tuber is applied } \\
\text { externally in snake bite } \\
\text { for } 4-5 \text { days. }\end{array}$ & $\begin{array}{l}\text { A beautiful climbing } \\
\text { glabrous herb with } \\
\text { leafy tendrils and } \\
\text { fleshy cylindrical } \\
\text { tubers; leaves sessile, }\end{array}$ \\
\hline
\end{tabular}




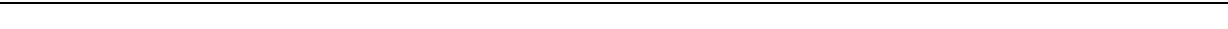

opposite or alternate; flowers axillary, solitary and forming a terminal corymb; capsules oblong and about 4.7 cm long.

\begin{tabular}{|c|c|c|c|c|}
\hline Compositae & & & & \\
\hline $\begin{array}{l}\text { Ageratina adeno } \\
\text { phora (Spreng.) } \\
\text { R.M.King \& } \\
\text { H.Rob. }\end{array}$ & $\begin{array}{l}\text { Catweed / } \\
\text { Baseda / } \\
\text { Kala Bansa / } \\
\text { Kala } \\
\text { Padhina }\end{array}$ & UAU222 & $\begin{array}{l}\text { Herb / } \\
\text { leaf }\end{array}$ & $\begin{array}{l}\text { Juice (5-10 drops) or } \\
\text { paste ( } 1-2 \mathrm{~g}) \text { of fresh } \\
\text { leaves is applied on } \\
\text { wounds and cuts twice a } \\
\text { day for } 3-5 \text { days to heal } \\
\text { the damaged part. The } \\
\text { juice efficiently } \\
\text { coagulates the blood of } \\
\text { fresh-cut. }\end{array}$ \\
\hline
\end{tabular}

\begin{tabular}{|c|c|c|c|c|}
\hline $\begin{array}{l}\text { Ageratum } \\
\text { conyzoides (L.) } \\
\text { L. }\end{array}$ & $\begin{array}{l}\text { Goatweed / } \\
\text { Jangali } \\
\text { Pudia / } \\
\text { Padhina / } \\
\text { Visamustih }\end{array}$ & UAU223 & $\begin{array}{l}\text { Herb / } \\
\text { leaf }\end{array}$ & $\begin{array}{l}\text { Juice (5-10 drops) or } \\
\text { paste ( } 1-2 \mathrm{~g} \text { ) of fresh } \\
\text { leaves is applied on } \\
\text { wounds and cuts twice a } \\
\text { day for } 3-5 \text { days to heal } \\
\text { the damaged part. The } \\
\text { juice efficiently } \\
\text { coagulates the blood of } \\
\text { fresh-cut. }\end{array}$ \\
\hline
\end{tabular}

An erect bushy, leafy, many-stemmed, perennial shrub, about 100-200 cm long; leaves dark green, slightly hairy, oppositely arranged; flowers white sticky hairy, produce cluster; seeds tiny, light brown to black.

An erect, hairy, tropical annual herb of 30-100 $\mathrm{cm}$ high; stems and leaves covered with fine white hairs, possess a weak aromatic unpleasant smell; flowers violet or white, forms cluster at end of the branches; fruits glabrous, about $0.16 \mathrm{~cm}$ long; seeds dark with scales.

\begin{tabular}{llll}
\hline Anacyclus & Spanish & UAU224 & Herb / \\
pyrethrum (L.) & Chamomile / & & leaf or \\
Lag. & Akarkara & & root
\end{tabular}

A small quantity of fresh leaves or roots is pressed between teeth to relieve toothache. This treatment is also effective in controlling cavity formation and gingivitis by inhibiting bacterial infection.

A perennial herb with numerous stems; flowers born at the branch-end of a stem; leaves alternate, smooth, pinnate; root cylindrical, slightly twisted, crowned with a cluster of grey hair.

\begin{tabular}{|c|c|c|c|c|}
\hline Crassulaceae & & & & \\
\hline $\begin{array}{l}\text { Bryophyllum } \\
\text { pinnatum (Lam.) } \\
\text { Oken }\end{array}$ & $\begin{array}{l}\text { Pashanbhed } \\
\text { a / Air plant / } \\
\text { Pattharchatt } \\
\text { a / Dard }\end{array}$ & UAU225 & $\begin{array}{l}\text { Herb / } \\
\text { leaf }\end{array}$ & $\begin{array}{l}\text { Fresh leaves (1-2) } \\
\text { slightly fried in edible oil } \\
\text { are applied on boils twice } \\
\text { a day for several days. }\end{array}$ \\
\hline
\end{tabular}

\begin{tabular}{|c|c|c|c|c|c|}
\hline \multirow{2}{*}{\multicolumn{5}{|c|}{ Cucurbitaceae }} & \multirow[t]{2}{*}{ campanulate tube. } \\
\hline & & & & & \\
\hline $\begin{array}{l}\text { Citrullus } \\
\text { colocynthis (L.) } \\
\text { Schrad. }\end{array}$ & $\begin{array}{l}\text { Bitter } \\
\text { Cucumber / } \\
\text { Peetpushpi / } \\
\text { Indravaruni }\end{array}$ & UAU226 & $\begin{array}{l}\text { Climber / } \\
\text { root }\end{array}$ & $\begin{array}{l}\text { Juice }(3-5 \mathrm{~mL}) \text { of fresh } \\
\text { roots diluted with water is } \\
\text { given to children with } \\
\text { stomachache. One } \\
\text { teaspoon of crushed } \\
\text { fresh roots can also be } \\
\text { given followed by some } \\
\text { water in the complaint of } \\
\text { a stomachache. It is also } \\
\text { useful in chest pain due } \\
\text { to unknown reasons. }\end{array}$ & $\begin{array}{l}\text { An annual vine with } \\
\text { trailing herbaceous } \\
\text { stems with rough hairs; } \\
\text { leaves alternate, } \\
\text { triangular-shaped, } \\
\text { hairy; flowers yellow, } \\
\text { singly at axils; fruits } \\
\text { globose, yellow and } \\
\text { smooth; seeds ovate } \\
\text { compressed, white or } \\
\text { brownish. }\end{array}$ \\
\hline \multicolumn{6}{|l|}{ Gentianaceae } \\
\hline $\begin{array}{l}\text { Gentiana kurroo } \\
\text { Royle }\end{array}$ & $\begin{array}{l}\text { Trayamana/ } \\
\text { Himalayan } \\
\text { Gentian / } \\
\end{array}$ & UAU227 & $\begin{array}{l}\text { Herb / } \\
\text { root }\end{array}$ & $\begin{array}{l}\text { Decoction of roots }(2-3 \mathrm{~g}) \\
\text { is used in any type of }\end{array}$ & $\begin{array}{l}\text { A critically endangered } \\
\text { Himalayan herb; } \\
\text { flowers deep blue, }\end{array}$ \\
\hline
\end{tabular}

\section{A perennial, glabrous} and succulent herb grows up to $100 \mathrm{~cm}$ high; leaves simple, lobed or compound; flower pendulous, cylindrical; petals united in a united in a flowers deep blue, 


\begin{tabular}{lll}
\hline India & fever, mainly against & funnel-shaped; leaves \\
Gentian / & typhoid fever. & $\begin{array}{l}\text { lance-shaped; stems } \\
\text { several, unbranched, } \\
\text { Kadu }\end{array}$ \\
& & $\begin{array}{l}\text { arising from a stout } \\
\text { rootstock. }\end{array}$ \\
\hline
\end{tabular}

\begin{tabular}{|c|c|c|c|}
\hline Lamiaceae & & & \\
\hline $\begin{array}{l}\text { Mentha } \times \text { piperita } \\
\text { L. }\end{array}$ & $\begin{array}{l}\text { Peppermint / UAU228 } \\
\text { Pudina }\end{array}$ & $\begin{array}{l}\text { Herb / } \\
\text { leaf }\end{array}$ & $\begin{array}{l}\text { Juice or paste of fresh } \\
\text { leaves is applied on the } \\
\text { forehead in headache } \\
\text { and fever. }\end{array}$ \\
\hline
\end{tabular}

\begin{tabular}{|c|c|c|c|c|}
\hline $\begin{array}{l}\text { Roylea cinerea } \\
\text { (D.Don) Baill. }\end{array}$ & $\begin{array}{l}\text { Ashy roylea / } \\
\text { Titpatti / } \\
\text { Kadui }\end{array}$ & UAU229 & $\begin{array}{l}\text { Shrub / } \\
\text { leaf or } \\
\text { root }\end{array}$ & $\begin{array}{l}\text { Juice }(5-10 \mathrm{~mL}) \text { of fresh } \\
\text { leaves is diluted with } \\
\text { water and drank in all } \\
\text { types of fever. Decoction/ } \\
\text { infusion of fresh leaves is } \\
\text { also consumed in place } \\
\text { of juice. Roots power (1- } \\
2 \mathrm{~g} \text { ) as a whole or in the } \\
\text { form of a decoction is } \\
\text { also used in fever. }\end{array}$ \\
\hline Vitex negundo L. & $\begin{array}{l}\text { Sinduvara / } \\
\text { Chaste tree / } \\
\text { Nirgundi / } \\
\text { Shimlu }\end{array}$ & UAU230 & $\begin{array}{l}\text { Shrub / } \\
\text { leaf }\end{array}$ & $\begin{array}{l}\text { The essence of fresh } \\
\text { leaves by crushing them } \\
\text { between two palms is } \\
\text { inhaled in common cold } \\
\text { and catarrh. }\end{array}$ \\
\hline
\end{tabular}

An erect, aromatic, perennial herb; leaves petioled, opposite, ovate; flowers light pink, borne in thick terminal spikes.

A perennial shrub; leaves ovate, toothed to almost lobed, flat; stem greyish velvety; flower-spikes having 412 flowers with separated clusters; flowers white or pink. and catarrh.

A deciduous shrub of
$1-3$ height; leaf
foliolate, leaflets
lanceolate; stem grey;
flowers bluish-purple,
borne in lateral cymes;
drupe succulent and
black when ripe; seeds
obovate or oblong.

\section{Leguminosae \\ Cajanus cajan} (L.) Millsp.

Pigeon pea /
Arhar / Tor

Pigeon pea
Arhar / Tor

\section{Shrub /} leaf

\section{Five to ten fresh apical} immature leaves are chewed for 5-10 minute for mouth ulcer and the leftover pulp in the mouth is spilt out. The treatment can be adopted 2 to 3 days once at any time.

\begin{tabular}{llll}
\hline Lablab & Lablab bean & UAU232 & Climber / \\
purpureus (L.) & / Sem / & & leaf \\
Sweet (Syn. & Chhemi & &
\end{tabular}

Dolichos lablab

L.) Juice prepared from fresh leaves is externally applied for the treatment of fungal infection of the rectum and anus in children. Topical application of fresh leaf paste is used to treat ringworm. The fresh leaf is also rubbed on the infected areas.

An erect annual shrub of 1-3 m; leaf pointed trifoliate; flower yellow or red; pods green, several pods produced in clusters; seeds 3-5 per pod.

An annual vine; leaves have three pointed leaflets, hairy on underneath; inflorescence made up of racemes of many white, purplish or blue flowers; fruit pod bright purple to pale green; seeds 3-4 white, brown, red or black. Decoction (100-200 mL) A twining annual herb made up of 5-10 g of with trifoliate leaves; seeds is given in kidney leaflets ovate, rounded stone thrice a day for several days. at the base; flowers yellow or greenishyellow; pods $6-8 \mathrm{~cm}$ long with 5-7 seeds. A small tree, growing to $5-8 \mathrm{~m}$; leaves alternate, trifoliate with three leaflets; flowers arise in short racemes; fruit $6-9 \mathrm{~cm}$ long pod with $1-2$ seeds.

\begin{tabular}{|c|c|c|c|c|c|}
\hline $\begin{array}{l}\text { Pterocarpus } \\
\text { santalinus L.f. }\end{array}$ & $\begin{array}{l}\text { Chandan / } \\
\text { Sandalwood }\end{array}$ & UAU234 & $\begin{array}{l}\text { Tree / } \\
\text { stem }\end{array}$ & $\begin{array}{l}\text { Paste of fresh bark } \\
\text { prepared by boiling the } \\
\text { crushed material with a } \\
\text { small amount of water, is } \\
\text { applied to the fractured } \\
\text { bone in the form of } \\
\text { poultice using a cotton }\end{array}$ & $\begin{array}{l}\text { A small tree, growing } \\
\text { to } 5-8 \text { m; leaves } \\
\text { alternate, trifoliate with } \\
\text { three leaflets; flowers } \\
\text { arise in short racemes; } \\
\text { fruit } 6-9 \mathrm{~cm} \text { long pod } \\
\text { with } 1-2 \text { seeds. }\end{array}$ \\
\hline
\end{tabular}
cloth. The paste is 


\begin{tabular}{|c|c|c|c|c|c|}
\hline & & & & $\begin{array}{l}\text { effective in increasing } \\
\text { bone density, reducing } \\
\text { pain and inflammation. } \\
\text { The paste is also used } \\
\text { with the bark of Prunus } \\
\text { cerasoides for better } \\
\text { results. }\end{array}$ & \\
\hline $\begin{array}{l}\text { Uraria picta } \\
\text { (Jacq.) DC. }\end{array}$ & $\begin{array}{l}\text { Prishniparni } \\
\text { / Dabra / } \\
\text { Pitvan / } \\
\text { Shankaraja }\end{array}$ & UAU235 & $\begin{array}{l}\text { Shrub / } \\
\text { leaf }\end{array}$ & $\begin{array}{l}\text { Decoction of dried leaves } \\
\text { powder }(2-5 \mathrm{~g}) \text { is given } \\
\text { orally twice a day for } \\
\text { several days to stop the } \\
\text { bleeding of internal } \\
\text { wounds, ulcer, dysentery } \\
\text { and piles. }\end{array}$ & $\begin{array}{l}\text { An erect perennial, } \\
\text { under-shrub, up to } 180 \\
\text { cm long; branches } \\
\text { velvety; lower leaves } \\
1-3 \text {, upper leaves 5-9 } \\
\text { foliolate; flower purple, } \\
\text { pink or bluish; fruit 5-9 } \\
\text { cm long with 3-6 } \\
\text { segments. }\end{array}$ \\
\hline \multicolumn{6}{|l|}{ Liliaceae } \\
\hline Allium cepa L. & $\begin{array}{l}\text { Palandu / } \\
\text { Onion / Pyaz }\end{array}$ & UAU236 & $\begin{array}{l}\text { Herb / } \\
\text { bulb }\end{array}$ & $\begin{array}{l}\text { Crushed bulb after } \\
\text { roasted in fire is applied } \\
\text { on boils for several hours } \\
\text { to stop the growth of } \\
\text { boils and relieve pain. }\end{array}$ & $\begin{array}{l}\text { A biennial herb with } \\
\text { aromatic fleshy } \\
\text { underground bulb; } \\
\text { leaves hollow, } \\
\text { cylindrical; flowers } \\
\text { white, globular umbels; } \\
\text { bulb multilayered, } \\
\text { peppery and spicy } \\
\text { flavoured. }\end{array}$ \\
\hline \multicolumn{6}{|l|}{ Musaceae } \\
\hline $\begin{array}{l}\text { Musa } \times \\
\text { paradisiaca L. }\end{array}$ & $\begin{array}{l}\text { Banana / } \\
\text { Kadli / Kela }\end{array}$ & UAU237 & $\begin{array}{l}\text { Herb / } \\
\text { stem }\end{array}$ & $\begin{array}{l}\text { Fresh aqueous juice (2-3 } \\
\text { drops) of the stem is } \\
\text { used externally for eyes } \\
\text { problems. }\end{array}$ & $\begin{array}{l}\text { A tropical tree-like } \\
\text { evergreen herb; leaves } \\
\text { large, overlapping } \\
\text { bases; stem } \\
\text { cylindrical, multi- } \\
\text { layered; flowers } \\
\text { developed from the } \\
\text { centre of the crown; } \\
\text { each plant bears fruit } \\
\text { once. }\end{array}$ \\
\hline \multicolumn{6}{|l|}{ Myrtaceae } \\
\hline $\begin{array}{l}\text { Psidium guajava } \\
\text { L. }\end{array}$ & $\begin{array}{l}\text { Guava / } \\
\text { Amarud }\end{array}$ & UAU238 & $\begin{array}{l}\text { Tree / } \\
\text { leaf }\end{array}$ & $\begin{array}{l}\text { The fresh apical } \\
\text { immature leaves (1-2 } \\
\text { leaves) of Psidium } \\
\text { guajava (Psidium guava } \\
\text { Griseb.) are chewed for } \\
5-10 \text { minute for mouth } \\
\text { ulcer and spill out after } \\
\text { that from the mouth. }\end{array}$ & $\begin{array}{l}\text { A small tree with } \\
\text { spreading branches; } \\
\text { stem bark smooth and } \\
\text { thin with copper- } \\
\text { coloured flakes; } \\
\text { flowers borne in small } \\
\text { clusters; fruit round, } \\
\text { ovoid or pear-shaped, } \\
\text { sweet when ripe. }\end{array}$ \\
\hline \multicolumn{6}{|l|}{ Nyctaginaceae } \\
\hline $\begin{array}{l}\text { Boerhavia diffusa } \\
\text { L. }\end{array}$ & $\begin{array}{l}\text { Punarnava / } \\
\text { Hogweed }\end{array}$ & UAU239 & $\begin{array}{l}\text { Herb / } \\
\text { root }\end{array}$ & $\begin{array}{l}\text { Fresh root }(1-2 \mathrm{~g}) \text { is } \\
\text { chewed twice a day for } \\
\text { several days in jaundice. } \\
\text { Root powder }(1-2 \mathrm{~g}) \text { is } \\
\text { taken with boil water or } \\
\text { milk in stomach ache due } \\
\text { to lifting heavy objects. } \\
\text { The powder is given in } \\
\text { muscular and joint pain } \\
\text { due to rheumatoid } \\
\text { arthritis. }\end{array}$ & $\begin{array}{l}\text { A perennial herb with } \\
\text { stout rootstock and } \\
\text { many procumbent } \\
\text { branches; leaves } \\
\text { simple, opposite; } \\
\text { flowers pale rose, } \\
\text { small, short-stalked; } \\
\text { fruits viscid, easily } \\
\text { detachable, one- } \\
\text { seeded. }\end{array}$ \\
\hline \multicolumn{6}{|l|}{ Piperaceae } \\
\hline Piper longum L. & $\begin{array}{l}\text { Pipali / Long } \\
\text { peeper }\end{array}$ & UAU240 & $\begin{array}{l}\text { Shrub / } \\
\text { leaf }\end{array}$ & $\begin{array}{l}\text { Paste of freshly crushed } \\
\text { leaves is applied to the } \\
\text { ringworm. Juice obtained } \\
\text { by squeezing fresh } \\
\text { leaves is also applied in }\end{array}$ & $\begin{array}{l}\text { A scandent shrub or } \\
\text { climber; leaf ovate, } \\
\text { acute at apex, cordate } \\
\text { and strongly oblique at } \\
\text { the base; root } \\
\text { perennial woody; stem }\end{array}$ \\
\hline
\end{tabular}




\begin{tabular}{|c|c|c|c|c|c|}
\hline & & & & $\begin{array}{l}\text { the infected areas } \\
\text { including the face. }\end{array}$ & $\begin{array}{l}\text { creeping and jointed; } \\
\text { flowers monoecious, } \\
\text { male and female } \\
\text { flowers borne on } \\
\text { different plants; fruit } \\
\text { fleshy embedded in } \\
\text { spikes; berry glabrous } \\
\text { and black or deep red. }\end{array}$ \\
\hline \multicolumn{6}{|l|}{ Plantaginaceae } \\
\hline $\begin{array}{l}\text { Picrorhiza kurroa } \\
\text { Royle ex Benth. }\end{array}$ & $\begin{array}{l}\text { Kutki / } \\
\text { Costus / } \\
\text { Kuth / } \\
\text { Kedarkaru }\end{array}$ & UAU241 & $\begin{array}{l}\text { Herb / } \\
\text { root }\end{array}$ & $\begin{array}{l}\text { Decoction of crushed } \\
\text { fresh root }(1 \mathrm{~g}) \text {, boiled } \\
\text { with one cup of water } \\
\text { until the volume remains } \\
\text { half, is consumed as a } \\
\text { tea once a day for } \\
\text { several days in joints } \\
\text { pain, weakness, cough } \\
\text { and respiratory } \\
\text { problems. Tea of fresh } \\
\text { leaves is given in } \\
\text { bronchial asthma due to } \\
\text { its expectorant property. }\end{array}$ & $\begin{array}{l}\text { A perennial, } \\
\text { rhizomatous herb with } \\
\text { spoon-shaped leaves; } \\
\text { rhizome long and } \\
\text { woody; flowers small, } \\
\text { pale or purplish-blue } \\
\text { with long stamens. }\end{array}$ \\
\hline \multicolumn{6}{|l|}{ Polygonaceae } \\
\hline $\begin{array}{l}\text { Rheum australe } \\
\text { D. Don (Syn. } \\
\text { Rheum emodii } \\
\text { Wall. ex Meisn.) }\end{array}$ & $\begin{array}{l}\text { Indian } \\
\text { rhubarb / } \\
\text { Himalayan } \\
\text { rhubarb / } \\
\text { Revatchini / } \\
\text { Archu }\end{array}$ & UAU242 & $\begin{array}{l}\text { Herb / } \\
\text { root }\end{array}$ & $\begin{array}{l}\text { Root paste is externally } \\
\text { applied for muscular pain } \\
\text { and swelling. Poultice of } \\
\text { the fresh roots is applied } \\
\text { on the affected parts } \\
\text { thrice a day for } 1-3 \text { days. }\end{array}$ & $\begin{array}{l}\text { A small herb with stout } \\
\text { roots and leafy stem; } \\
\text { leaves cordate, long- } \\
\text { petioled, orbicular; } \\
\text { flowers pale-red; } \\
\text { nutlets ovoid-oblong } \\
\text { with cordate base and } \\
\text { notched apex. }\end{array}$ \\
\hline $\begin{array}{l}\text { Rumex hastatus } \\
\text { D. Don. }\end{array}$ & $\begin{array}{l}\text { Arrowleaf } \\
\text { dock / } \\
\text { Churki / } \\
\text { Almoru / } \\
\text { Amildu }\end{array}$ & UAU243 & $\begin{array}{l}\text { Shrub / } \\
\text { leaf }\end{array}$ & $\begin{array}{l}\text { Leaves paste is applied } \\
\text { externally on cuts, } \\
\text { blisters and sore. A thick } \\
\text { layer of the paste is } \\
\text { applied twice a day for } 3- \\
5 \text { days for better results. }\end{array}$ & $\begin{array}{l}\text { A small and bushy } \\
\text { shrub with many } \\
\text { ascending stems; } \\
\text { leaves narrow and } \\
\text { arrow-shaped; flowers } \\
\text { tiny greenish pink; } \\
\text { flower-stalk } \\
\text { lengthening in fruit. }\end{array}$ \\
\hline \multicolumn{6}{|l|}{ Ranunculaceae } \\
\hline $\begin{array}{l}\text { Aconitum } \\
\text { heterophyllum } \\
\text { Wall. ex Royle }\end{array}$ & $\begin{array}{l}\text { Ativisha / } \\
\text { Atees }\end{array}$ & UAU244 & $\begin{array}{l}\text { Herb / } \\
\text { root }\end{array}$ & $\begin{array}{l}\text { Tea of fresh roots }(2 \mathrm{~g}) \text { is } \\
\text { given in fever. }\end{array}$ & $\begin{array}{l}\text { A perennial herb up to } \\
120 \mathrm{~cm} \text { tall; flowers } \\
\text { large greenish-purple, } \\
\text { darker-veined, having } \\
\text { spike-like clusters; } \\
\text { leaves ovate-heart- } \\
\text { shaped to rounded; } \\
\text { seed pods hairy, erect. }\end{array}$ \\
\hline $\begin{array}{l}\text { Delphinium } \\
\text { denudatum Wall. } \\
\text { ex Hook.f. \& } \\
\text { Thomson }\end{array}$ & $\begin{array}{l}\text { Nirvisha / } \\
\text { Jadwar }\end{array}$ & UAU245 & $\begin{array}{l}\text { Herb / } \\
\text { leaf }\end{array}$ & $\begin{array}{l}\text { Paste of fresh leaves } \\
\text { with mustard oil is } \\
\text { applied on the wounds } \\
\text { and cut for } 1-3 \text { days. It } \\
\text { also stops the bleeding } \\
\text { of cuts. }\end{array}$ & $\begin{array}{l}\text { A critically endangered } \\
\text { Himalayan herb; } \\
\text { leaves } 5-15 \mathrm{~cm} \text { across, } \\
\text { rounded in outline; } \\
\text { flower small blue or } \\
\text { violet, borne in the } \\
\text { branched } \\
\text { inflorescence with } \\
\text { spike-like clusters. }\end{array}$ \\
\hline $\begin{array}{l}\text { Thalictrum } \\
\text { foliolosum DC. }\end{array}$ & $\begin{array}{l}\text { Mamira / } \\
\text { Pilijari }\end{array}$ & UAU246 & $\begin{array}{l}\text { Herb / } \\
\text { root }\end{array}$ & $\begin{array}{l}\text { Fresh roots }(1-2 \mathrm{~g}) \text { are } \\
\text { either chewed as a whole } \\
\text { or consumed in the form } \\
\text { of a decoction in } \\
\text { jaundice. The treatment } \\
\text { is taken two to three } \\
\text { times a day for several } \\
\text { days. It is also used as a } \\
\text { liver tonic. }\end{array}$ & $\begin{array}{l}\text { An erect, rigid, } \\
\text { perennial herb; } \\
\text { rootstock fibrous, } \\
\text { yellowish-brown, } \\
\text { extremely bitter; } \\
\text { flowers pale-green, } \\
\text { arising in branched } \\
\text { terminal panicles; } \\
\text { leaves pinnately }\end{array}$ \\
\hline
\end{tabular}




\begin{tabular}{|c|c|c|c|c|c|}
\hline & & & & & $\begin{array}{l}\text { decompounded; } \\
\text { leaflets sub-orbicular, } \\
\text { slightly lobulated. }\end{array}$ \\
\hline \multicolumn{6}{|l|}{ Rosaceae } \\
\hline $\begin{array}{l}\text { Prunus } \\
\text { cerasoides } \\
\text { Buch.-Ham. ex } \\
\text { D.Don }\end{array}$ & $\begin{array}{l}\text { Padmakasth } \\
\text { am / Bird } \\
\text { cherry / } \\
\text { Himalayan } \\
\text { Wild Cherry / } \\
\text { Padmakasth } \\
\text { / Painya / } \\
\text { Pajha }\end{array}$ & UAU247 & $\begin{array}{l}\text { Tree / } \\
\text { stem } \\
\text { bark }\end{array}$ & $\begin{array}{l}\text { A thick paste of fresh } \\
\text { bark, crushed and } \\
\text { cooked with a little } \\
\text { amount of water, is } \\
\text { applied externally with } \\
\text { the help of cloth on the } \\
\text { inflammation of joints. A } \\
\text { poultice of the paste is } \\
\text { applied to the fractured } \\
\text { bone area for several } \\
\text { days to repair the broken } \\
\text { bone. The paste helps } \\
\text { reduce muscular pain } \\
\text { and other pains including } \\
\text { due to old fractures. The } \\
\text { paste is also applied in } \\
\text { combination with } \\
\text { Santalum album L. } \\
\text { (Indian sandalwood / } \\
\text { Chandan) for better } \\
\text { results. }\end{array}$ & $\begin{array}{l}\text { A medium-sized tree } \\
\text { grows up to } 30 \text { m high; } \\
\text { stem bark smooth and } \\
\text { peels off in thin } \\
\text { horizontal stripes; } \\
\text { leaves elliptic, long- } \\
\text { pointed; flowers pink, } \\
\text { long-stalked, paired or } \\
\text { few-flowered clusters } \\
\text { at the end of branches; } \\
\text { fruit yellow, maturing to } \\
\text { red. }\end{array}$ \\
\hline $\begin{array}{l}\text { Prunus persica } \\
\text { (L.) Batsch }\end{array}$ & $\begin{array}{l}\text { Aruka / } \\
\text { Peach / Aru }\end{array}$ & UAU248 & $\begin{array}{l}\text { Tree / } \\
\text { seed } \\
\text { pericarp } \\
\text { or leaf }\end{array}$ & $\begin{array}{l}\text { Paste of seed pericarp is } \\
\text { topically applied on } \\
\text { infection due to breakage } \\
\text { of hairs, folliculitis and } \\
\text { boils. Topical application } \\
\text { of fresh leaves paste or } \\
\text { juice ( } 5-10 \text { drops) is } \\
\text { effective for wounds by } \\
\text { protecting them from } \\
\text { further microbial } \\
\text { infections. }\end{array}$ & $\begin{array}{l}\text { A small tree up to } 8 \mathrm{~m} \\
\text { high; stem erect with } \\
\text { glabrous branched } \\
\text { twigs; leaves alternate, } \\
\text { simple, elliptic- } \\
\text { lanceolate; flowers } \\
\text { cup-shaped with pink } \\
\text { petals; fruit fleshy and } \\
\text { downy drupe enclosing } \\
\text { a hard furrowed one- } \\
\text { seeded stone. }\end{array}$ \\
\hline \multicolumn{6}{|l|}{ Rutaceae } \\
\hline $\begin{array}{l}\text { Zanthoxylum } \\
\text { armatum DC. }\end{array}$ & $\begin{array}{l}\text { Tumburu / } \\
\text { Tejovati }\end{array}$ & UAU249 & $\begin{array}{l}\text { Shrub / } \\
\text { stem or } \\
\text { seed }\end{array}$ & $\begin{array}{l}\text { The stem is used to } \\
\text { clean teeth like a brush } \\
\text { and it is effective in } \\
\text { toothache. Seeds are } \\
\text { used in toothache by } \\
\text { crushing the mature } \\
\text { seeds between two } \\
\text { teeth. }\end{array}$ & $\begin{array}{l}\text { A perennial shrub with } \\
\text { dense glabrous } \\
\text { foliage, straight pickles } \\
\text { on stems; leaves } \\
\text { compound, } \\
\text { imparipinnate, rachis } \\
\text { winged; leaflets } \\
\text { lanceolate, dark flossy } \\
\text { green; flowers yellow } \\
\text { or green; fruits reddish } \\
\text { sub-globose glabrous } \\
\text { follicles; seeds solitary, } \\
\text { shiny black. }\end{array}$ \\
\hline \multicolumn{6}{|l|}{ Saxifragaceae } \\
\hline $\begin{array}{l}\text { Bergenia ciliata } \\
\text { (Haw.) Sternb. }\end{array}$ & $\begin{array}{l}\text { Fringed } \\
\text { elephant's } \\
\text { ears / Winter } \\
\text { begonia / } \\
\text { Pashanbhed }\end{array}$ & UAU250 & $\begin{array}{l}\text { Herb / } \\
\text { root }\end{array}$ & $\begin{array}{l}\text { Fresh or dried mature } \\
\text { roots }(1-3 \mathrm{~g}) \text { are chewed } \\
\text { in kidney stone twice a } \\
\text { day for several days. The } \\
\text { decoction of dried roots } \\
(1-3 \mathrm{~g}) \text { is also taken in } \\
\text { place of raw roots. }\end{array}$ & $\begin{array}{l}\text { An evergreen herb } \\
\text { with fleshy leaves, } \\
\text { stout creeping } \\
\text { rhizomatous rootstock; } \\
\text { leaves glabrous, } \\
\text { sparsely hairy in } \\
\text { margins, obovate or } \\
\text { elliptic; flowers white } \\
\text { pink; fruits capsules, } \\
\text { rounded with } \\
\text { numerous seeds. }\end{array}$ \\
\hline \multicolumn{6}{|l|}{ Violaceae } \\
\hline Viola odorata L. & $\begin{array}{l}\text { Benfasha / } \\
\text { Wood violet }\end{array}$ & UAU251 & $\begin{array}{l}\text { Herb / } \\
\text { leaf }\end{array}$ & $\begin{array}{l}\text { Fresh leaves }(2-3 \mathrm{~g}) \text { are } \\
\text { taken as whole or in the } \\
\text { form of a decoction in }\end{array}$ & $\begin{array}{l}\text { A small perennial herb; } \\
\text { leaves and flowers all } \\
\text { in a basal rosette; }\end{array}$ \\
\hline
\end{tabular}




\begin{tabular}{|c|c|c|c|c|c|}
\hline & & & & $\begin{array}{l}\text { fever. A tea of fresh roots } \\
(3 \mathrm{~g} \text { in } 1 \text { cup of water) is } \\
\text { effective in cold and } \\
\text { fever. }\end{array}$ & $\begin{array}{l}\text { hooked style and hairy } \\
\text { leaf-stalks. }\end{array}$ \\
\hline \multicolumn{6}{|l|}{ Vitaceae } \\
\hline $\begin{array}{l}\text { Cissus } \\
\text { quadrangularis L. }\end{array}$ & $\begin{array}{l}\text { Hatjod / Veld } \\
\text { grape }\end{array}$ & UAU252 & $\begin{array}{l}\text { Climber / } \\
\text { stem or } \\
\text { root }\end{array}$ & $\begin{array}{l}\text { Decoction of stems or } \\
\text { roots }(2 \mathrm{~g}) \text { is used to heal } \\
\text { fractured bones. Paste of } \\
\text { stems or roots is applied } \\
\text { at the damaged areas to } \\
\text { reduce inflammation and } \\
\text { pain. }\end{array}$ & $\begin{array}{l}\text { An evergreen climber } \\
\text { growing up to } 5 \mathrm{~m} \text {, } \\
\text { having quadrangular- } \\
\text { sectioned branches } \\
\text { with small internodes; } \\
\text { leaves toothed } \\
\text { trilobed, appeared at } \\
\text { the nodes; flowers } \\
\text { white, yellowish or } \\
\text { greenish in racemes. }\end{array}$ \\
\hline
\end{tabular}

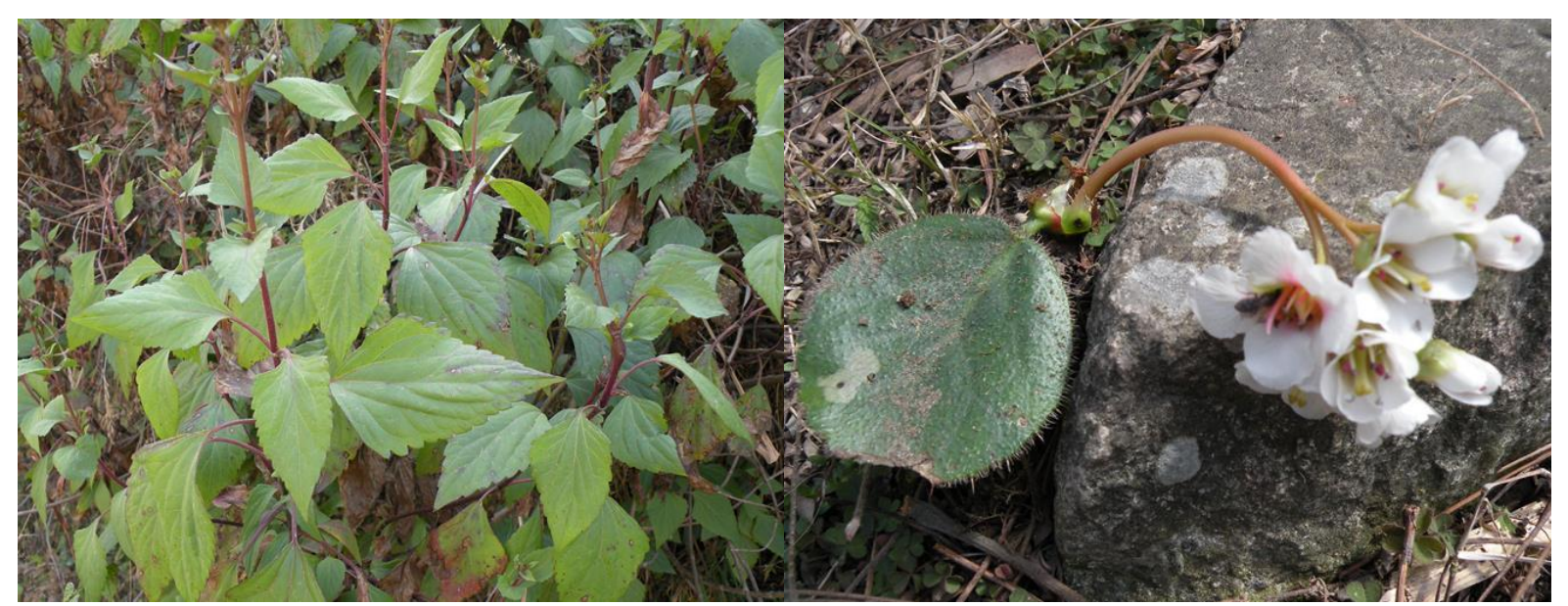

Ageratina adenophora

Bergenia ciliata

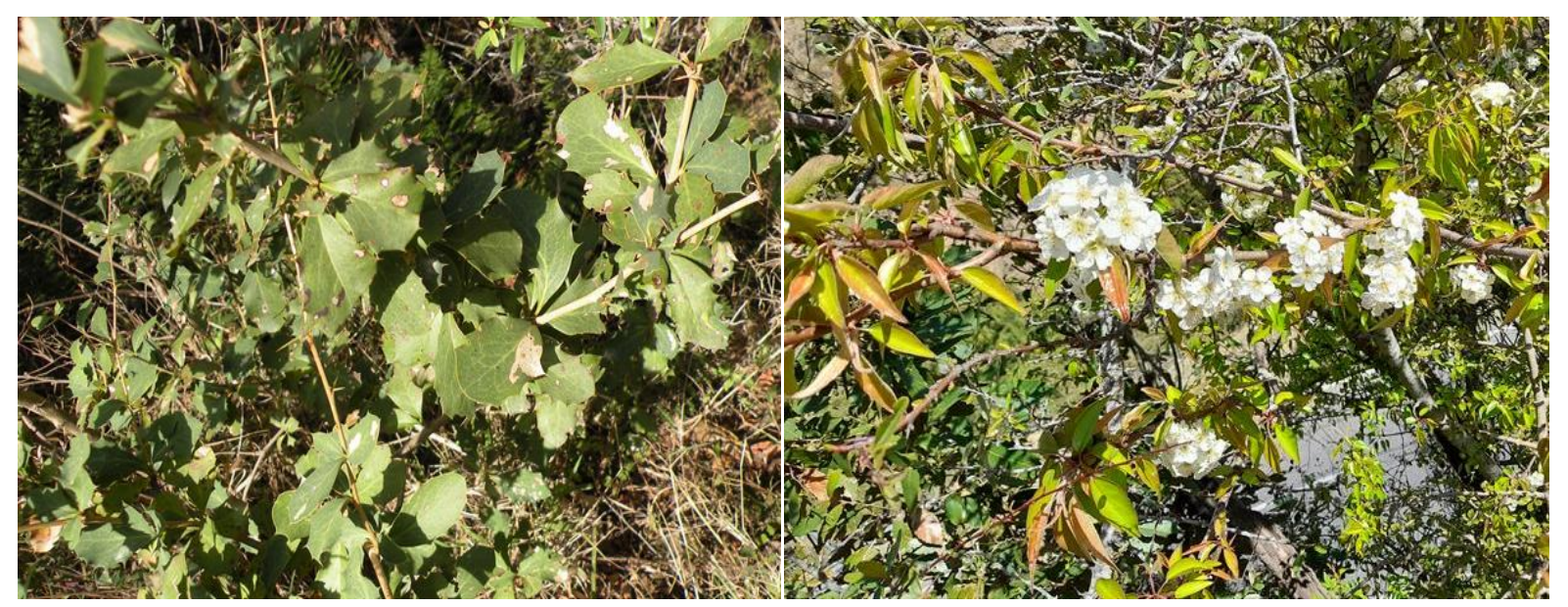

Berberis aristata

Prunus cerasoides 


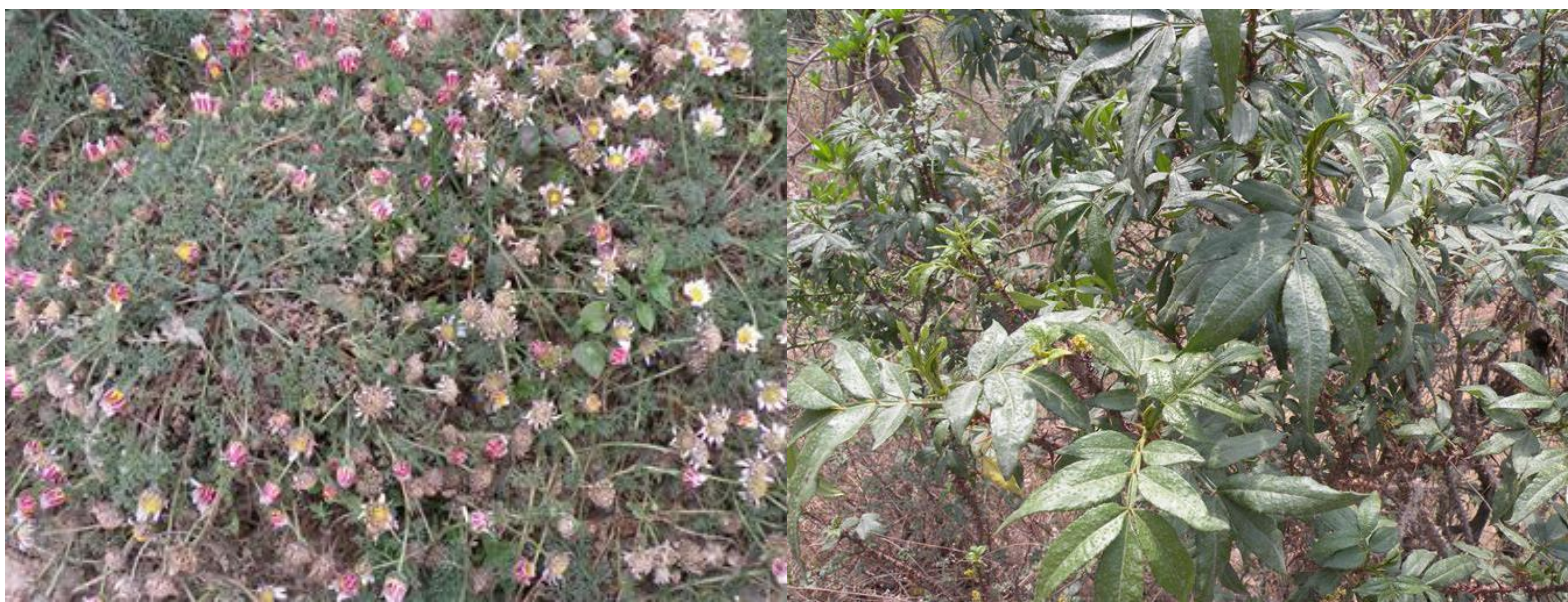

Anacyclus pyrethrum

Zanthoxylum armatum

Fig. 7. Images of selected medicinal plants captured from their natural habitats

Table 2. Major bioactives of selected folklore medicinal plants

\begin{tabular}{|c|c|c|c|}
\hline S.No. & Plant name & Bioactive compounds & Reference \\
\hline 1. & Picrorhiza kurroa & kutkoside, picroside-I, picroside-II & Ganeshkumar et al. 2017 \\
\hline 2. & Ageratum conyzoides & lycopsamine, echinatine & Wiedenfeld 2011 \\
\hline 3. & Ageratina adenophora & $\begin{array}{l}\text { eupatorone, neochlorogenic acid, } \\
\text { macranthoin } F \text {, macranthoin } G\end{array}$ & Poudel et al. 2020 \\
\hline 4. & Delphinium denudatum & $\begin{array}{l}\text { talatizidine, isotalatizidine, condelphine, } \\
\text { denudatine }\end{array}$ & $\begin{array}{l}\text { Mohanapriya \& } \\
\text { Vijaiyansiva } 2013\end{array}$ \\
\hline 5. & Holarrhena pubescens & $\begin{array}{l}\text { ursolic acid, lupeol, naringin and its } \\
\text { glycosides }\end{array}$ & $\begin{array}{l}\text { Tuntiwachwuttikul et al. } \\
2007\end{array}$ \\
\hline 6. & Prunus persica & quercetin, catechin, cyanidin & Bento et al. 2020 \\
\hline 7. & Bryophyllum pinnatum & $\begin{array}{l}\text { bryophillin A, bersaldegenin-3-acetate, } \\
\text { bryophillin C }\end{array}$ & Supratman et al. 2001 \\
\hline 8. & Allium cepa & allicin & Bystrická et al. 2013 \\
\hline 9. & Picrorhiza kurroa & picroside I, II & Debnath et al. 2020 \\
\hline 10. & Cissus quadrangularis & quadrangularin $\mathrm{A}$, ascorbic acid & Chen et al. 2009 \\
\hline 11. & Pterocarpus santalinus & $\begin{array}{l}\text { santalin A, santalin B, savinin, calocedrin, } \\
\text { pterolinus } K \text {, pterolinus L }\end{array}$ & Bulle et al. 2016 \\
\hline 12. & Trachyspermum ammi & thymol, carvone, limonene, dillapiole & Bairwa et al. 2012 \\
\hline 13. & Piper longum & $\begin{array}{l}\text { piperine, piperlongumine, sylvatin, sesamin, } \\
\text { diaeudesmin piperlonguminine, } \\
\text { pipermonaline, piperundecalidine }\end{array}$ & Kumar et al. 2011 \\
\hline 14. & Vitex negundo & casticin, isoorientin, chrysophenol D, luteolin & $\begin{array}{l}\text { Ambika \& Sundrarajan } \\
2015\end{array}$ \\
\hline 15. & Boerhavia diffusa & boerhaavia G, boerhavia $\mathrm{H}$ & $\begin{array}{l}\text { Ahmed-Belkacem et al. } \\
2007\end{array}$ \\
\hline 16. & Thalictrum foliolosum & berberine, jatrorrhizine, palmatine & Sharma et al. 2020 \\
\hline 17. & Rheum australe & emodin, chrysophanol & Pandith et al. 2018 \\
\hline
\end{tabular}




\section{Discussion}

The results of the present study revealed that cuts, wounds, boils, bone-fracture, joint pain, fungal infection, cough, cold, asthma, mouth ulcer, headache, jaundice, muscular pain, swelling, kidney stone, toothache, fever, snakebite, intestinal parasites, eyes related problems and stomachache are the main health conditions treated by the folk healers with the help of herbal medicine. Most of the above health conditions are associated with acute pain and inflammation and require emergency management (Abdolrazaghnejad et al. 2018). Hence, the traditional knowledge of healers of these rural areas is playing a key role in the primary healthcare of a large population using natural remedies. Moreover, herbal remedies are the best choice of treatment due to their high efficacy with no serious side effects.

It has been noticed that most of the ethnomedicinal herbs were used topically mainly for the treatment of cuts, wounds and bone fractures. However, the oral application of selected herbs was recorded for a few health conditions including stomachache and intestinal worms. Although the oral administration of a drug is most accepted, the topical route has many advantages over due to its easy application at a selective site and minimum side effects (Sharadha et al. 2020). Hence, it can be considered safe to use an herbal remedy via a topical route even without consulting a practitioner.

The results of the present field survey were found encouraging as many plants species were explored for their traditional uses for the first time. The present work can be considered as an extension of the field surveys conducted earlier by various researchers. Previous studies on the ethnobotanical survey of medicinal plants of other areas of Uttarakhand shows that the Gujjar tribe of Sub-Himalayan tract uses leaf or root of Vitex negundo, Withania somnifera and Senna tora for boils, leaf or stem bark of Dalbergia sissoo for eczema and fruits of Abrus precatorius and Plumbago zeylanica for leucoderma (Sharma et al. 2013). On the other hand, in the Siwalik region, inhabitants use Adhatoda vasica for rheumatism, cough and intestinal worms, Achyranthes aspera for skin diseases and colic conditions while Carissa opaca and Quirivelia frutescens were used for fever, skin disease and toothache (Gaur \& Sharma 2011). The field studies on the Pauri region revealed that the bark of Acacia catechu is used for waist pain, leaves of Adhatoda vasica with Piper nigrum for bronchitis and tuberculosis, roots of Boerhaavia diffusa with ghee for redness of the eyes, the leaf powder of Adiantum capillus-veneris for menstruation problems, juice of Chenopodium album for urinary problems whereas fruit or seed powder of Rubus niveus, leaves of Ocimum basilicum and Cynodon dactylon are used for calculi by the natives (Dangwal \& Sharma 2011; Khajuria \& Bisht 2017). Traditional healers of this region also used the seed oil of Madhuca longifolia for bodyache, leaf paste of Delphinium denudatum for burns and leaf paste of Cyperus rotundus for the treatment of skin ailments (Pandey \& Pandey 2010). Apart from common ailments, the inhabitants also used various plants for psychomedicinal purposes that include Stephania glabra, Betula utili and Prunus cerasoides (Tiwari et al. 2010).

Ethnobotanical field surveys play a key role in the new drug discovery from natural products (Albuquerque et al. 2014). Such studies are not limited to a certain region but extensively conducted worldwide viz. Asia (Xiong et al. 2020), Africa (Van Wyk et al. 2008), America (Botsaris 2007), Europe (Pieroni et al. 2013) and Australia (Thompson et al. 2019). To date, several medicinal products have been developed from natural sources and used extensively across the globe. Still, there are many remote areas having rich plant diversity, that are unexplored, the ethnobotanical survey of such areas may help find a solution to different untreatable chronic diseases including cancers.

\section{Conclusions}

The present survey-based study revealed that a major part of Jaunsar-Bawar region of Uttarakhand is remote in location. The rural population of this region still depends on folk medicine due to limited access to advanced medical facilities. Although in the nearby towns hospital facilities are also available, many people cannot afford the costly treatment. Hence, the folk knowledge of herbal remedies is no less than a boon for the inhabitants of this region. Interestingly, these plants are effective in treating various ailments without showing any adverse effect as being practised for centuries. However, their scientific validation with the proper mode of action is necessary to develop them as a medicine for commercial use. 


\section{Declarations}

List of abbreviations: Not applicable. Ethics approval and consent to participate: All the participants provided prior informed consent before the interviews.

Funding: This research was funded by the National Medicinal Plants Board, Ministry of AYUSH, Govt. of India (Grant No. Z.18017/187/CSS/R\&D/UK01/2017-18-NMPB-IV A).

Consent for publication: Verbal consent was obtained from participants who are identifiable in the article.

Availability of data and materials: Please contact the author for data requests.

Conflict of interest: The authors declare that they have no conflict of interests.

Author Contributions: Deepak Kumar Semwal: Conceptualization and designing the study, Supervision, Data collection and formal analysis, Review and editing; Ankit Kumar: Data collection and formal analysis, Writing original draft; Ashutosh Chauhan: Data collection and formal analysis; Ruchi Badoni Semwal: Validation and Visualization; Ravindra Semwal: Writing original draft; Sunil Kumar Joshi: Review and editing.

\section{Literature cited}

Abdolrazaghnejad A, Banaie M, Tavakoli N, Safdari M, Rajabpour-Sanati A. 2018. Pain Management in the Emergency Department: a Review Article on Options and Methods. Advanced Journal of Emergency Medicine 2(4):e45.

Adhikari M, Thapa R, Kunwar RM, Devkota HP, Poudel P. 2019. Ethnomedicinal Uses of Plant Resources in the Machhapuchchhre Rural Municipality of Kaski District, Nepal. Medicines 6(2):69.

Ahmed-Belkacem A, MacAlou S, Borrelli F, Capasso R, Fattorusso E, Taglialatela-Scafati O, Di Pietro A. 2007. Nonprenylated rotenoids, a new class of potent breast cancer resistance protein inhibitors. Journal of Medicinal Chemistry 50(8):1933-1938.

Albuquerque UP, de Medeiros PM, Ramos MA, Ferreira WS, Nascimento ALB, Avilez WMT, de Melo JG. 2014. Are ethnopharmacological surveys useful for the discovery and development of drugs from medicinal plants? Revista Brasileira de Farmacognosia 24(2):110-115.

Ambika S, Sundrarajan M. 2015. Antibacterial behaviour of Vitex negundo extract assisted $\mathrm{ZnO}$ nanoparticles against pathogenic bacteria. Journal of Photochemistry and Photobiology B 146:52-57.

Bairwa R, Sodha RS, Rajawat BS. 2012. Trachyspermum ammi. Pharmacognosy Reviews 6(11):56-60.
Bento C, Gonçalves AC, Silva B, Silva LR. 2020.

Peach (Prunus Persica): Phytochemicals and

Health Benefits. Food Reviews International. E-Pub ahead of print.

https://doi.org/10.1080/87559129.2020.1837861

Botsaris AS. 2007. Plants used traditionally to treat malaria in Brazil: the archives of Flora Medicinal. Journal of Ethnobiology and Ethnomedicine 3:18.

Bulle S, Reddyvari $\mathrm{H}$, Nallanchakravarthula $\mathrm{V}$, Vaddi DR. 2016. Therapeutic Potential of Pterocarpus santalinus L.: An Update. Pharmacognosy Reviews 10(19):43-49.

Bystrická J, Musilová J, Vollmannová A, Timoracká M, Kavalcová P. 2013. Bioactive components of onion (Allium cepa L.) - Review. Acta Alimentaria 42:11-22.

Chen J, He S, Mao H, Sun C, Pan Y. 2009. Characterization of polyphenol compounds from the roots and stems of Parthenocissus laetevirens by high-performance liquid chromatography/tandem mass spectrometry. Rapid Communications in Mass Spectrometry 23(6):737-44.

Dangwal LR, Sharma A. 2011. Indigenous traditional knowledge recorded on some medicinal plants in Narendra Nagar Block (Tehri Garhwal), Uttarakhand. Indian Journal of Natural Products and Resources 2(1):110-115.

Debnath P, Rathore S, Walia S, Kumar M, Devi R, Kumar R. 2020. Picrorhiza kurroa: a promising traditional therapeutic herb from higher altitude of western Himalayas. Journal of Herbal Medicine 23:100358.

Ganeshkumar Y, Ramarao A, Veeresham C. 2017. Picroside I and Picroside II from Tissue Cultures of Picrorhiza kurroa. Pharmacognosy research 9 (Suppl 1):S53-S56.

Gaur RD, Sharma J. 2011. Indigenous knowledge on the utilization of medicinal plant diversity in the Siwalik region of Garhwal Himalaya, Uttarakhand. Journal of Forest and Environmental Science 27(1):23-31.

Gaur RD. 1999. Flora of the District Garhwal, North West Himalaya: With Ethnobotanical Notes). TransMedia, Srinagar Garhwal, India.

Joshi B, Pant SC. 2012. Ethnobotanical study of some common plants used among the tribal communities of Kashipur, Uttarakhand. Indian Journal of Natural Products and Resources 3(2):262266.

Kanjilal UN. 2011. Forest Flora of the Chakrata, Dehra Dun and Saharanpur Forest Divisions, United Province. Bishen Singh Mahendra Pal Singh, Dehradun, India.

Khajuria AK, Bisht NS. 2017. Ethnomedicinal plants used to treat Nephrolithiasis: A case study Pauri 
(Pauri Garhwal), Uttarakhand. International Journal of Herbal Medicine 5(1):10-13.

Kumar A, Aswal S, Chauhan A, Semwal RB, Kumar A, Semwal DK. 2019. Ethnomedicinal Investigation of Medicinal Plants of Chakrata Region (Uttarakhand) Used in the Traditional Medicine for Diabetes by Jaunsari Tribe. Natural Products and Bioprospecting 9:175-200.

Kumar S, Kamboj J, Suman, Sharma S. 2011. Overview for Various Aspects of the Health Benefits of Piper Longum Linn. Fruit. Journal of Acupuncture and Meridian Studies 4(2):134-140.

Mohanapriya S. Vijaiyansiva G. 2013. Bioactive constituent of Delphinium denudatum wall. And their antioxidant efficacy. Journal of Academia and Industrial Research 2(2):138-141.

Pandey K. Pandey S. 2010. Indigenous medicines of Raji tribes of Uttarakhand. Indian Journal of Traditional Knowledge 9(1):131-133.

Pandith SA, Dar RA, Lattoo SK, Shah MA, Reshi ZA. 2018. Rheum australe, an endangered high-value medicinal herb of North Western Himalayas: a review of its botany, ethnomedical uses, phytochemistry and pharmacology. Phytochemistry Reviews 17(3):573-609.

Pieroni A, Pardo-de-Santayana M, Firenzuoli F. Quave CL. 2013. The European Heritage of Folk Medicines and Medicinal Foods: Its Contribution to the CAMs of Tomorrow. Evidence-Based Complementary and Alternative Medicine 2013:827521.

Poudel R, Neupane NP, Mukeri IH, Alok S, Verma A. 2020. An updated review on invasive nature, phytochemical evaluation, \& pharmacological activity of Ageratina adenophora. International Journal of Pharmaceutical Sciences and Research 11(6):2510-2520.

Semwal DK, Chauhan A, Kumar A, Aswal S, Semwal RB, Kumar A. 2019. Status of Indian medicinal plants in the International Union for Conservation of Nature and the future of Ayurvedic drugs: Shouldn't think about Ayurvedic fundamentals? Journal of Integrative Medicine 17(4):238-243.

Shah NC. 1982. Herbal folk medicines in northern India. Journal of Ethnopharmacology 6(3):293-301. Sharadha M, Gowda DV, Gupta NV, Akhila AR. 2020. An overview on topical drug delivery system Updated review. International Journal of Research in Pharmaceutical Sciences 11(1):368-385.

Sharma J, Gaur RD, Gairola S, Painuli RM, Siddiqi TO. 2013. Traditional herbal medicines used for the treatment of skin disorders by the Gujjar tribe of SubHimalayan tract, Uttarakhand. Indian Journal of Traditional Knowledge 12(4):736-746.

Sharma N, Kumar V, Chopra MP, Sourirajan A, Dev K, El-Shazly M. 2020. Thalictrum foliolosum: A lesser unexplored medicinal herb from the Himalayan region as a source of valuable benzyl isoquinoline alkaloids. Journal of Ethnopharmacology, 255:112736.

Shrestha PM, Dhillion SS. 2003. Medicinal plant diversity and use in the highlands of Dolakha district, Nepal. Journal of Ethnopharmacology 86(1):81-96.

Singh A, Hart R, Chandra S, Nautiyal MC, Sayok AK. 2019. Traditional Herbal Knowledge among the Inhabitants: A Case Study in Urgam Valley of Chamoli Garhwal, Uttarakhand, India. EvidenceBased Complementary and Alternative Medicine 2019:5656925.

Singh AG, Kumar A, Tewari DD. 2012. An ethnobotanical survey of medicinal plants used in Terai forest of western Nepal. Journal of Ethnobiology and Ethnomedicine 8:19.

Supratman U, Fujita T, Akiyama K, Hayashi $\mathrm{H}$, Murakami A, Sakai H, Koshimizu K, Ohigashi H. 2001. Anti-tumor promoting activity of bufadienolides from Kalanchoe pinnata and $K$. daigremontiana $x$ tubiflora. Bioscience, Biotechnology, and Biochemistry 65(4):947-949.

Thompson A, Munkara G, Kantilla M, Tipungwuti J. 2019. Medicinal plant use in two Tiwi Island communities: a qualitative research study. Journal of Ethnobiology and Ethnomedicine 15:40.

Tiwari JK, Ballabha R, Tiwari P. 2010. Ethnopaediatrics in Garhwal Himalaya, Uttarakhand, India (Psychomedicine and Medicine). New York Science Journal 3(4):123-126.

Tuntiwachwuttikul $\mathrm{P}$, Pootaeng-on $\mathrm{Y}$, Phansa $\mathrm{P}$, Limpachayaporn $P$, Charoenchai $P$, Taylor WC. 2007. Constituents of the leaves of Holarrhena pubescens. Fitoterapia 78(3):271-273.

Van Wyk BE, de Wet $\mathrm{H}$, Van Heerden FR. 2008. An ethnobotanical survey of medicinal plants in the southeastern Karoo, South Africa. South African Journal of Botany 74(4):696-704.

WHO. 2019. WHO global report on traditional and complementary medicine. Geneva: World Health Organization.

https://apps.who.int/iris/handle/10665/312342.

Wiedenfeld H. 2011. Plants containing pyrrolizidine alkaloids: toxicity and problems. Food Additives \& Contaminants A 28(3):282-292.

Xiong Y, Sui X, Ahmed S, Wang Z, Long C. 2020. Ethnobotany and diversity of medicinal plants used by the Buyi in eastern Yunnan, China. Plant Diversity 42(6):401-414. 